\title{
Anna Kiersztyn Niepewność zatrudnienia młodych dorosłych: analiza sekwencji karier zawodowych ${ }^{1}$
}

\begin{tabular}{|c|c|}
\hline \multicolumn{2}{|c|}{$\begin{array}{l}\text { Job insecurity among young adults: an analysis of employment career sequences } \\
\text { The article looks at the results of a quantitative study of employment insecurity among young adults in } \\
\text { Poland. Insecurity is conceptualized as a specific career sequence, observed over several years, composed } \\
\text { of recurrent episodes of non-standard employment separated by periods of joblessness. The empirical part } \\
\text { of the analysis uses data from the three most recent waves of the Polish Panel Survey POLPAN (conducted in } \\
2008,2013 \text {, and 2018). It offers an analysis of the employment transitions experienced by the respondents, } \\
\text { a description of early career sequences (covering a period of three or five years following graduation), and } \\
\text { an assessment of the main socio-economic correlates of persistent youth employment insecurity on the } \\
\text { Polish labour market. }\end{array}$} \\
\hline DOI & https://doi.org/10.31268/StudiaBAS.2020.14 \\
\hline Słowa kluczowe & $\begin{array}{l}\text { młodzi dorośli, niepewność na rynku pracy, sekwencje karier } \\
\text { zawodowych, struktura społeczna w Polsce, zatrudnienie na czas } \\
\text { określony }\end{array}$ \\
\hline Keywords & $\begin{array}{l}\text { young adults, labour market insecurity, career sequences, social } \\
\text { structure in Poland, fixed-term employment }\end{array}$ \\
\hline O autorce & $\begin{array}{l}\text { doktor habilitowany w dziedzinie nauk społecznych, Instytut Socjologii, } \\
\text { Uniwersytet Warszawski • } ₫ \text { chaber@is.uw.edu.pl • } \\
\text { ORCID 0000-0001-8112-6059 }\end{array}$ \\
\hline
\end{tabular}

\section{Wstęp}

W ostatnich dekadach globalizacja ekonomiczna i rozwój technologiczny, umożliwiające lokowanie zakładów produkcyjnych w krajach oferujących tanią siłę roboczą, spowodowały coraz silniejszą presję na obniżanie kosztów zatrudnienia i liberalizację prawa pracy. Efektem tego była rosnąca popularność tzw. niestandardowych czy elastycznych form zatrudnienia, do których zalicza się m.in.: umowy o pracę na czas określony, umowy cywilnoprawne bądź wynajem pracowników od agencji pracy tymczasowej. Powyższą zmianę często interpretowano jako przejaw przechodzenia od modelu stabilnego zatrudnienia na pełnym etacie do modelu karier będących zlepkiem epizodów tymczasowych prac². Ten wyłaniający się wzór kariery był charakteryzowany przez socjologów jako naznaczony ryzykiem i niepewnością, skazujący pracowników na życie z dnia na dzień3

1 Niniejszy artykuł został przygotowany w ramach projektu „Dynamika niepewności zatrudnienia młodych: uwarunkowania, trajektorie i skutki w perspektywie porównawczej" finansowanego przez Narodowe Centrum Nauki (grant nr 2018/31/B/HS6/02043).

2 Zob. np. A.L. Kalleberg, Precarious work, insecure workers: employment relations in transition, „American Sociological Review" 2009, vol. 74, no. 1, https://doi.org/10.1177/000312240907400101.

3 Np. Z. Bauman, Płynna nowoczesność, Wydawnictwo Literackie, Kraków 2006; R. Sennett, Korozja charakteru. Osobiste konsekwencje pracy w nowym kapitalizmie, Muza, Warszawa 2006. 
Podobne obawy znalazły wyraz w szeroko dyskutowanym pojęciu prekariatu, który - według jego twórcy Guya Standinga - jest nową klasą społeczną, składającą się z osób zatrudnionych na tymczasowych kontraktach, o niskich dochodach i bez dostępu do systemu świadczeń socjalnych, borykających się z niepewnością ekonomiczną i poczuciem tymczasowości ${ }^{4}$ W literaturze podkreśla się, że powyższe tendencje dotykają w szczególności młodych absolwentów, którzy relatywnie częściej doświadczają trudności w znalezieniu zatrudnienia, częściej pracują na czas określony i są bardziej zagrożeni utratą pracy ${ }^{5}$.

Powyższe zagadnienia mają odniesienie do sytuacji w Polsce. Wskazują na to dane pochodzące z Badań Aktywności Ekonomicznej Ludności (BAEL), zgodnie z którymi odsetek pracowników zatrudnionych na czas określony w ostatnich latach był zbliżony do $27 \%$, co stanowi niemal dwukrotność średniej dla całej Unii Europejskiej. Wskaźniki odsetka zatrudnionych na czas określony w przedziałach wiekowych 15-24 lata oraz 25-34 lata w Polsce od dawna pozostają jednymi z najwyższych na tle innych krajów Unii Europejskiej. Przykładowo, w 2018 r. dla obu przedziałów wiekowych w Polsce wyniosły odpowiednio - 62,6\% i 30,5\%, średnie dla całej Unii Europejskiej zaś - 43,5\% i 18,5\% ${ }^{6}$. Dostępne dane wskazują też na znaczący wśród młodych udział zatrudnionych niebędących w stosunku pracy (pracujących na podstawie umów cywilnoprawnych) oraz problem pracujących biednych? ${ }^{7}$.

Prekaryzacja zatrudnienia jest ważnym przedmiotem analiz z uwagi na możliwe indywidualne i społeczne koszty, które może za sobą pociągać. Badania dowiodły, że praca na czas określony zwiększa ryzyko depresji i problemów zdrowotnych ${ }^{8}$, może też pogłębiać negatywne tendencje demograficzne w wyniku odraczania przez młodych momentu założenia rodziny i decyzji o posiadaniu potomstwa ${ }^{9}$. Niepewność zatrudnienia może też oddziaływać na poziom i charakter uczestnictwa jednostek w życiu społeczno-politycznym, a także na kondycję wspólnoty obywatelskiej ${ }^{10}$. Celem niniejszego artykułu jest diagnoza skali i społeczno-ekonomicznych

4 G. Standing, Prekariat. Nowa niebezpieczna klasa, Wydawnictwo Naukowe PWN, Warszawa 2014.

5 A. Aassve, E. Cottini, A. Vitali, Youth prospects in a time of economic recession, "Demographic Research" 2013, vol. 29, no. 36, https://doi.org/10.4054/DemRes.2013.29.36; M. Mills, H.-P. Blossfeld, Globalization, uncertainty and the early life course: A theoretical framework [w:] Globalization, uncertainty and youth in society, red. H.-P. Blossfeld, E. Klijzing, M. Mills, K. Kurz, Routledge, London-New York 2005. Zob. też K. Szafraniec, Młodzi 2011, Kancelaria Prezesa Rady Ministrów, Warszawa 2011.

6 Baza danych Eurostat, https://ec.europa.eu/eurostat/web/ffs/data/database [dostęp: 24 czerwca 2020 r.].

7 M. Karolak, Społeczno-ekonomiczne konteksty prekaryzacji pracy młodych w Polsce [w:] Oswajanie niepewności. Studia społeczno-ekonomiczne nad młodymi pracownikami sprekaryzowanymi, red. A. Mrozowicki, J. Czarzasty, Wydawnictwo Naukowe Scholar, Warszawa 2020.

8 A. Quesnel-Vallee, S. DeHaney, A. Ciampi, Temporary work and depressive symptoms: A propensity score analysis, „Social Science and Medicine" 2010, vol. 70, no. 12, https://doi.org/10.1177/0143831X14559781; M. Virtanen et al., Temporary employment and health: a review, „International Journal of Epidemiology" 2005, vol. 34, no. 3, https://doi.org/10.1093/ije/dyi024.

9 C. Schmitt, Labour market integration, occupational uncertainties, and fertility choices in Germany and the UK, „Demographic Research” 2012, vol. 26, no. 12, https://doi.org/10.4054/DemRes.2012.26.12.

10 Wyniki badań dotyczących tego, jak trudności na rynku pracy mogą wpływać na zachowania i postawy polityczne, zostały szczegółowo opisane w: A. Kiersztyn, Labour market precarity and political alienation, „Przegląd Socjologiczny" 2018, t. 67, nr 3, https://doi.org/10.26485/Ps/2018/67.3/2; A. Kiersztyn, Voice and 
korelatów niepewności na rynku pracy wśród osób rozpoczynających życie zawodowe w Polsce, dokonana na podstawie analizy sekwencji karier młodych dorosłych. Przyjęto socjologiczną definicję kariery zawodowej jako sekwencji prac, które ludzie podejmują od momentu wejścia na rynek pracy ${ }^{11}$. Za moment wejścia na rynek pracy uznaje się ukończenie edukacji, „młoda dorosłość" jest zaś definiowana jako obejmująca okres od ukończenia edukacji do 35 roku życia.

\section{Pomiar niepewności zatrudnienia}

Mimo dość powszechnej świadomości wagi problemu niepewności na rynku pracy i jego potencjalnie dalekosiężnych skutków dla społeczeństwa badacze wciąż napotykają trudności związane z jasnym zdefiniowaniem zjawiska prekaryjnego zatrudnienia i jego systematyczną, ilościową analizą ${ }^{12}$. Wiele badań koncentruje się na rodzaju umowy, na podstawie której jest świadczona praca ${ }^{13}$. Takie analizy nie zawsze odwołują się bezpośrednio do pojęcia prekaryzacji rynku pracy, lecz opierają się na założeniu, że niestandardowe formy zatrudnienia, takie jak zatrudnienie na czas określony lub praca tymczasowa (w niektórych przypadkach także praca w niepełnym wymiarze godzin), wiążą się z gorszymi warunkami pracy i niepewną przyszłością. Powyższe założenie jest problematyczne z uwagi na fakt, iż pomija się w nim znaczne zróżnicowanie sytuacji i perspektyw zawodowych poszczególnych pracowników z umowami na czas określony. Perspektywy te są bowiem zależne od tego, czy w danej sytuacji umowy tego typu

Insecurity. Political Participation among Members of the Precariat [w:] Civil Society Revisited: Lessons from Poland, red. K. Jacobsson, E. Korolczuk, Berghahn Books, New York-Oxford 2017.

11 K.M. Słomczyński, Wprowadzenie. Kariera i sukces jako przedmiot badań socjologicznych [w:] Kariera i sukces. Analizy socjologiczne, red. K.M. Słomczyński, Uniwersytet Zielonogórski, Zielona Góra 2007. Zob. też: A. Cybal-Michalska, Młodzież w relacji do kariery jako "własności" zawodu albo „roli zawodowej" - perspektywa funkcjonalno-strukturalna, „Studia Edukacyjne” 2016, nr 38, https://doi.org/10.14746/se.2016.38.4; M. Piorunek, Kariera według młodych, czyli nowy paradygmat kariery na dysonansowym rynku pracy, , Studia Edukacyjne” 2016, nr 38, https://doi.org/10.14746/se.2016.38.6. W odróżnieniu od typowego ujęcia kariery, w którym kluczową rolę odgrywa wymiar awansu zawodowego bądź osiągania pewnych celów związanych z życiem zawodowym, w analizowanych sekwencjach nie przyjęto żadnych założeń co do określonego bądź pożądanego kierunku mobilności zawodowej. W tym sensie wykorzystana w ramach analizy koncepcja kariery różni się też od ujęć funkcjonujących w dziedzinie psychologii czy poradnictwa zawodowego.

12 Zob.: A. Kiersztyn, Non-standard employment and subjective insecurity. How can we capture job precarity using survey data? [w:] Precarious Work, Research in the Sociology of Work Series, red. A. Kalleberg, S. Vallas, Emerald Publishing, Bingley 2017; A. Mrozowicki et al., Prekaryzacja pracy a świadomośćspołeczna i strategie życiowe ludzi młodych: ramy teoretyczne [w:] Oswajanie niepewności. Studia społeczno-ekonomiczne nad młodymi pracownikami sprekaryzowanymi, red. A. Mrozowicki, J. Czarzasty, Wydawnictwo Naukowe Scholar, Warszawa 2020.

13 Np. artykuł sprzed kilku lat prezentujący wyniki dla Polski to M. Barański, Determinants of Temporary Employment in Poland, „Warsaw Forum of Economic Sociology” 2014, vol. 5, no. 1(9). Nowsze prace to: L. Hipp, J. Bernhardt, J. Allmendinger, Institutions and the Prevalence of Nonstandard Employment, "Socio-Economic Review" 2015, vol. 13, no. 2, https://doi.org/10.1093/ser/mwv002; W. Lewchuk, Precarious Jobs: Where Are They, and How Do They Affect Well-Being?, "The Economic and Labour Relations Review” 2017, vol. 28, no. 3, https://doi.org/10.1177/1035304617722943; B. Högberg, M. Strandh, A. Baranowska-Rataj, Transitions from Temporary Employment to Permanent Employment among Young Adults: The Role of Labour Law and Education Systems, ,Journal of Sociology" 2019, vol. 55, no. 4, https://doi.org/10.1177/1440783319876997. 
stanowią dla pracowników „pomost” (ang. stepping-stone) do stabilnego zatrudnienia, czy też „ślepy zaułek" (ang. trap) ${ }^{14}$.

Mechanizm pomostu jest uzasadniany poprzez wskazanie, iż zatrudnienie tymczasowe może, zwłaszcza wśród młodych absolwentów, stanowić dobrą okazję do zdobycia doświadczenia zawodowego, zwiększającego późniejsze szanse na rynku pracy. W wielu krajach jakaś forma tymczasowego zatrudnienia stosowana jest rutynowo wobec nowo przyjętych pracowników w firmach, zwłaszcza na stanowiska wymagające wyższych umiejętności, jako środek pozwalający pracodawcom na „przetestowanie” nowego pracownika przed zatrudnieniem na stałe ${ }^{15}$. Innymi słowy: wśród osób, które pracują, mając niestandardowe umowy, ważną liczebnie kategorię stanowić mogą osoby zatrudnione na okres próbny, z których jakaś część uzyska stałe zatrudnienie.

Hipoteza „ślepego zaułka” jest wywodzona z teorii dualnego rynku pracy ${ }^{16}$. Teoria ta zakłada trwały podział rynku pracy na dwa odrębne, wzajemnie nieprzenikające się segmenty - pierwotny i wtórny. Pierwotny segment oferuje stabilne zatrudnienie, dobre warunki pracy i możliwość awansu zawodowego, na wtórnym dominują zaś krótkoterminowe, nisko płatne prace, niewymagające specjalistycznych kwalifikacji. Łatwa zastępowalność pracowników w drugim segmencie wiąże się z ich gorszą pozycją przetargową w relacjach z pracodawcami, brak trwałej więzi między pracodawcą a pracownikiem z kolei sprawia, iż temu pierwszemu nie opłaca się inwestować w doskonalenie zawodowe zatrudnionych przez siebie osób ${ }^{17}$. Ponadto z uwagi na ograniczoną mobilność pracowników pomiędzy segmentem wtórnym i pierwotnym powyższe trudności na ogół mają charakter trwały, a pracownicy w segmencie wtórnym zamiast osiągać stabilizację, przechodzą z jednej nisko płatnej pracy do kolejnej. Na podobny mechanizm w przypadku prac tymczasowych wskazują współcześnie wyniki zarówno polskich, jak i zagranicznych badań, w większości potwierdzające, że pracownicy zatrudnieni na czas określony znajdują się na ogół w gorszej sytuacji w porównaniu z pracownikami zatrudnionymi na stałe pod względem zarobków ${ }^{18}$, dostępu do świadczeń pracowniczych, a także szkoleń i programów podnoszenia kwalifikacji zawodowych finansowanych przez pracodawców ${ }^{19}$.

14 Istnieje wiele prac, których autorzy stosują to rozróżnienie i usiłują odpowiedzieć na pytanie, czy elastyczne zatrudnienie stanowi „pomost”, czy „ślepy zaułek” w różnych kontekstach. Np.: A.L. Booth, M. Francesconi, J. Frank, Temporary jobs: stepping stones or dead ends?, "The Economic Journal” 2002, vol. 112, no. 480, https:// doi.org/10.1111/1468-0297.00043; V. Gash, Bridge or trap? Temporary workers' transitions to unemployment and to the standard employment contract, „European Sociological Review” 2008, vol. 24, no. 5, https://doi. org/10.1093/esr/jcn027. Przykład nowszej pracy to B. Högberg, M. Strandh, A. Baranowska-Rataj, op. cit.

15 R. Faccini, Reassessing Labour Market Reforms: Temporary Contracts as a Screening Device, "The Economic Journal" 2013, vol. 124, no. 575, https://doi.org/10.1111/ecoj.12072.

16 P.B. Doeringer, M.J. Piore, Internal Labor Markets and Manpower Analysis, Heath Lexington Books, Lexington 1971.

17 W takiej sytuacji główną funkcją zatrudnienia na czas określony byłoby uzyskanie w firmach pewnej puli łatwo zastępowalnych pracowników, których liczbę można szybko i tanim kosztem dostosowywać do bieżących potrzeb wyznaczanych przez zmienny popyt na produkty i usługi danej firmy.

18 A. Kiersztyn, Fixed-Term Employment and Occupational Position in Poland: The Heterogeneity of Temporary Jobs, „European Sociological Review” 2016, vol. 32, no. 6, https://doi.org/10.1093/esr/jcw044.

19 Np.: P. McGovern, D. Smeaton, S. Hill, Bad Jobs in Britain. Nonstandard Employment and Job Quality, „,Work and Occupations" 2004, vol. 31, no. 2, https://doi.org/10.1177/0730888404263900; P.J. O'Connell, D. Byrne, The 
Powyższe niejasności skłoniły wielu badaczy do przyjęcia, że odpowiednim sposobem na uchwycenie niepewności zatrudnienia jest analiza wskaźników subiektywnych oszacowań ryzyka utraty pracy ${ }^{20}$ lub uwzględnienie deklaracji pracowników odnośnie do przyczyn podjęcia elastycznego zatrudnienia - tego, czy był to efekt ich indywidualnego wyboru ${ }^{21}$, czy zostało to wymuszone przez brak ofert stałej pracy ${ }^{22}$. Takie wskaźniki - choć same w sobie stanowią interesujący przedmiot badań - wprowadzają w błąd jako miary prekaryzacji ze względu na fakt, że są zależne od czynników innych niż obiektywne ryzyko związane z utratą pracy ${ }^{23}$. Psychologiczne mechanizmy adaptacji do doświadczanych przez jednostki trudności życiowych, a także dostęp do rozmaitych zasobów pozwalających złagodzić negatywne skutki utraty źródła dochodów mogą sprawić, że pracownicy zatrudnieni na czas określony nie będą postrzegać niepewności jako problematycznej. Zwłaszcza młodzi zwykle umniejszają ryzyko związane z elastycznymi formami zatrudnienia ${ }^{24}$, chociaż częściej doświadczają niepewności na rynku pracy niż starsi pracownicy. Takiej „normalizacji” prekaryjnej pracy sprzyja poczucie, że zatrudnienie tego typu jest powszechne i „oczywiste” (np. wymuszone realiami rynku pracy bądź specyfiką branży), a także procesy indywidualizacji ${ }^{25}$, które mogą wpływać na sposób, w jaki młodzi postrzegają i racjonalizują swoje doświadczenia na rynku pracy.

Z uwagi na przedstawione wyżej trudności adekwatna operacjonalizacja niepewności na rynku pracy powinna być oparta na danych opisujących obiektywną sytuację pracy poszczególnych osób, a nie na ich subiektywnej ocenie tej sytuacji. Powinna też uwzględniać zmiany sytuacji pracy na przestrzeni lat, dzięki czemu umożliwiłaby ustalenie, czy niestabilność zawodowa utrzymuje się przez dłuższy okres. W analizach przedstawionych poniżej niepewność na rynku

determinants and effects of training at work: bringing the work-place back in, "European Sociological Review" 2012, vol. 28, no. 3, https://doi.org/10.1093/esr/jcq063.

20 H. Chung, S. Mau, Subjective insecurity and the role of institutions, ,Journal of European Social Policy" 2014, vol. 24, no. 4, https://doi.org/10.1177/0958928714538214.

21 W literaturze można odnaleźć też argumenty wskazujące na to, że istnieje pewna wąska grupa tzw. pracowników bez granic (boundaryless employees), do której należą wysoko wykwalifikowani specjaliści, dobrowolnie podejmujący elastyczne zatrudnienie, jako gwarantujące większą niezależność i ochronę przed monotonią. Tacy pracownicy są w stanie wynegocjować korzystne warunki zatrudnienia: uzyskują wysokie wynagrodzenia i zajmują ważne stanowiska w swoich firmach. Zob. J.H. Marler, M. Barringer, G.T. Milkovich, Boundaryless and traditional contingent employees: Worlds apart, "Journal of Organizational Behavior" 2002, vol. 23, no. 4, https://doi.org/10.1002/job.148.

22 European Commission, Employment and Social Developments in Europe 2015, Publications Office of the European Union, Luxembourg 2016.

23 Wskazuje się np., że lęk przed utratą pracy jest silnie związany z koniunkturą ekonomiczną i może być często spotykany również wśród pracowników zatrudnionych na czas nieokreślony. Zob. np. R. Fevre, Employment Insecurity and Social Theory: The Power of Nightmares, „Work, Employment and Society” 2007, vol. 21, no. 3, https://doi.org/10.1177/0950017007080013.

24 A. Mrozowicki, Normalisation of Precariousness? Biographical Experiences of Young Workers in the Flexible Forms of Employment in Poland, „Przegląd Socjologii Jakościowej” 2016, t. 12, nr 2; L. Nyhagen Predelli, A. Cebulla, Perceptions of labour market risks: shifts and continuities across generations, "Current Sociology” 2011, vol. 59, no. 1, https://doi.org/10.1177/0011392110385968.

25 U. Beck, E. Beck-Gernsheim, Individualisation: Institutionalized Individualism and Its Social and Political Consequences, Sage, London 2002. 
pracy jest pojmowana jako sekwencje karier ${ }^{26}$, na które składają się okresy powtarzającego się zatrudnienia na czas określony przeplatane okresami bezrobocia. Uchwycenie tego zjawiska jest możliwe dzięki analizie danych pochodzących z badań panelowych gromadzących informacje o respondentach na przestrzeni wielu lat.

\section{Wczesne etapy karier zawodowych w świetle danych POLPAN}

Do przedstawionych w niniejszym artykule analiz wykorzystano dane pochodzące z najnowszej edycji Polskiego Badania Panelowego POLPAN. Jest to badanie kwestionariuszowe realizowane od 1988 r. na ogólnopolskiej próbie reprezentatywnej: ci sami respondenci są badani w pięcioletnich odstępach, próba badawcza jest zaś regularnie uzupełniana o losowo dobrane podpróby najmłodszych kohort ${ }^{27}$. Ostatnia fala badania miała miejsce w 2018 r. POLPAN jest szczególnie wartościowy w kontekście podejmowanej problematyki badawczej z kilku powodów. Po pierwsze, jest jedynym polskim badaniem, w ramach którego są gromadzone szczegółowe dane retrospektywne dotyczące każdej pracy podjętej w okresie między kolejnymi falami panelu, co umożliwia odtworzenie pełnych historii karier zawodowych respondentów. Po drugie, dane gromadzone w jego trakcie zawierają bardzo szczegółową charakterystykę prac respondentów. Jest to rzecz godna podkreślenia, ponieważ inne dostępne badania, choć oparte na większych próbach, nie umożliwiają równie długich analiz panelowych (maksymalna długość panelu to 4 lata w przypadku badania EU-SILC) i nie dostarczają równie bogatych informacji o przebiegu kariery zawodowej. Choć zakres i sposób budowania pytań o formę zatrudnienia zmieniały się między poszczególnymi falami, to ze względu na niniejszą analizę istotny jest fakt, iż dane POLPAN - począwszy od 2008 r. - umożliwiają dość precyzyjne odróżnienie umów o pracę na czas nieokreślony i na czas określony od innych elastycznych form zatrudnienia, w szczególności umów cywilnoprawnych (umów o dzieło bądź umów-zleceń) ${ }^{28}$.

26 W światowej literaturze poświęconej niepewności zatrudnienia analizy sekwencji karier stają się w ostatnich latach coraz bardziej istotne. Zob. np.: S. Fenton, E. Dermott, Fragmented Careers?: Winners and Losers in Young Adult Labour Markets, „Work, Employment and Society” 2006, vol. 20, no. 2, https://doi. org/10.1177/0950017006064111; S. Fuller, N. Stecy-Hildebrandt, Career Pathways for Temporary Workers: Exploring Heterogeneous Mobility Dynamics with Sequence Analysis, "Social Science Research” 2015, vol. 50, https://doi.org/10.1016/j.ssresearch.2014.11.003.

27 Dokładne informacje o strukturze próby w badaniach POLPAN, jak również szczegółowy opis metodologii oraz kwestionariusze stosowane w poszczególnych falach są dostępne na stronie internetowej projektu: www.polpan.org.

28 W badaniach z 2008 r. pytanie o formę zatrudnienia dotyczyło wyłącznie prac najemnych trwających minimum 3 miesiące w wymiarze co najmniej 15 godzin tygodniowo i odróżniono w nim zatrudnienie z umową o pracę na czas określony od zatrudnienia z umową o pracę na czas nieokreślony; osoby, które nie posiadały umowy o pracę, lecz pracowały na kontraktach cywilnoprawnych bądź wykonywały pracę nierejestrowaną, były zaliczane do kategorii „inna sytuacja”. Ponadto pełne dane o rodzaju umowy w pracach zakończonych przed momentem badania nie były gromadzone w odniesieniu do wszystkich respondentów. W 2013 r. pytanie o kontrakt zatrudnienia było bardziej szczegółowe i objęło wszystkie prace najemne wykonywane przez respondentów od ostatniej edycji badania (lub od początku kariery w przypadku osób biorących udział w badaniu po raz pierwszy). Kategorie odpowiedzi do wyboru uwzględniały obok umów o pracę na czas 
Analizy przedstawione w niniejszym artykule były prowadzone na podpróbie osób w wieku 21-35 lat badanych w 2018 r., które przed badaniem zakończyły edukację ( $N=706)$. Uwzględniają wszystkie prace wykonywane przez respondentów od momentu zakończenia edukacji do badania w 2018 r. ${ }^{29}$; jeśli chodzi o starsze kohorty respondentów (w wieku powyżej 25 lat), którzy po raz pierwszy wzięli udział w badaniu POLPAN w latach 2008 lub 2013, do odtworzenia pełnego przebiegu karier wykorzystano również dane pochodzące z wcześniejszych fal badania. Ponieważ okres obserwacji historii karier różnił się w przypadku poszczególnych respondentów w zależności od roku ukończenia edukacji (najwcześniejszy rok ukończenia edukacji w badanej próbie to 1998, co oznacza dwudziestoletni okres obserwacji, jednak w próbie znalazły się również osoby, które ukończyły kształcenie w latach 2017 lub 2018), w analizach przebiegu karier próba została ograniczona do tych respondentów, którzy opuścili system edukacji co najmniej 3 lata lub 5 lat przed badaniem.

Tabela 1 przedstawia rozkład procentowy zatrudnienia respondentów bezpośrednio po zakończeniu edukacji ${ }^{30}$ oraz po 3 i 5 latach od jej zakończenia. Widoczny jest tu wysoki odsetek badanych, którzy nie podjęli pracy w okresie pierwszego półrocza po ukończeniu ostatniej szkoły bądź uczelni wyższej (36,5\%). Spośród pracujących respondentów mniej więcej co trzeci miał umowę o pracę na czas nieokreślony. Pozostali pracownicy nie posiadali stałego zatrudnienia, przy czym większość z nich miała umowy o pracę na czas określony. Niemniej co piąty absolwent w próbie POLPAN w swojej pierwszej pracy był pozbawiony ochrony wynikającej z Kodeksu pracy (w tej grupie większość stanowiły osoby pracujące na podstawie umów-zleceń bądź umów o dzieło) $)^{31}$. Wraz z upływem czasu od ukończenia edukacji spada odsetek pozostających bez pracy lub zatrudnionych bez umowy o pracę, rośnie zaś udział zatrudnionych

nieokreślony bądź określony również umowy-zlecenia, umowy o dzieło oraz pracę bez umowy pisemnej. W 2018 r. zastosowano nowy sposób pytania o kolejne prace respondenta i położono większy nacisk na wychwycenie zmian (wykonywanego zawodu, rodzaju pracy, szczegółowo opisanej formy zatrudnienia) w trakcie każdej pracy. Każda zmiana formy zatrudnienia, zawodu, stanowiska (również w ramach tej samej firmy) jest traktowana jako osobna praca, co umożliwia np. wychwycenie sytuacji przejścia z pracy na czas określony do stałej po okresie próbnym.

29 W sytuacji jednoczesnego wykonywania dwóch prac za pracę główną jest uznawana ta, która zajmuje najwięcej godzin w tygodniu; prace dodatkowe są pomijane w rekonstrukcji sekwencji karier. Jeśli respondent wykonuje pracę najemną w pełnym wymiarze czasu i jednocześnie pracuje jako właściciel gospodarstwa rolnego, za pracę główną jest uznawana praca najemna niezależnie od deklarowanej liczby godzin poświęconych na pracę we własnym gospodarstwie.

30 W ramach badania POLPAN respondenci pytani są tylko o rok ukończenia edukacji. Za miesiąc ukończenia szkół przyjęto czerwiec, za pierwszą pracę wykonywaną po ukończeniu edukacji - pierwszą pracę rozpoczętą w okresie lipiec-grudzień tego samego roku bądź - jeśli respondent nie rozpoczął w tym okresie żadnej nowej pracy - pracę rozpoczętą wcześniej i nadal wykonywaną w drugim półroczu roku ukończenia edukacji.

31 W przypadku prac, o których informacje uzyskano w badaniach POLPAN 2008, do tej kategorii zaliczono prace, w których podstawą zatrudnienia nie była umowa o pracę, oraz wszystkie prace dorywcze, które w POLPAN są definiowane jako zajmujące do 15 godzin tygodniowo lub wykonywane przez okres krótszy niż 3 miesiące. W POLPAN 2008 pytanie o rodzaj kontraktu nie pozwala bezpośrednio zidentyfikować osób zatrudnionych na podstawie umów cywilnoprawnych i wykonujących pracę nierejestrowaną. Analiza danych za 2013 r. ujawniła jednak, że niemal wszystkie prace dorywcze są wykonywane na podstawie umów cywilnoprawnych lub bez formalnej umowy. 
z umową o pracę na czas nieokreślony. Powyższe zmiany można interpretować jako świadczące o istnieniu mechanizmu „pomostu”. Należy jednak zwrócić uwagę, iż dane dotyczące sytuacji respondentów po 5 latach od opuszczenia przez nich systemu szkolnego nie pozwalają wnioskować o postępującej w miarę upływu lat stabilizacji młodych na rynku pracy. Nawet jeśli uznamy, iż samozatrudnienie zapewnia stabilność ekonomiczną i odpowiedni poziom zabezpieczeń socjalnych ${ }^{32}$, to $w$ dalszym ciągu połowa respondentów jest pozbawiona dostępu do pracy dającej stabilizację.

\section{Tabela 1. Zatrudnienie respondentów w wieku 21-35 lat (według POLPAN 2018) po ukończeniu edukacji, 3 lata później i 5 lat później (w \%)}

\begin{tabular}{|l|c|c|c|}
\hline & $\begin{array}{c}\text { Po ukończeniu } \\
\text { edukacjia }\end{array}$ & $\begin{array}{c}\text { Po } \mathbf{3} \text { latach od } \\
\text { ukończenia } \\
\text { edukacji }\end{array}$ & $\begin{array}{c}\text { Po } \mathbf{5} \text { latach od } \\
\text { ukończenia } \\
\text { edukacjic }\end{array}$ \\
\hline Pozostawanie bez pracy & 36,5 & 24,47 & 21,58 \\
\hline Zatrudnienie z umową o pracę na czas nieokreślony & 21,3 & 35,45 & 41,97 \\
\hline Zatrudnienie z umową o pracę na czas określony & 22,3 & 23,89 & 21,34 \\
\hline Brak umowy o pracę, w tym umowy cywilnoprawne & 14,1 & 9,25 & 6,71 \\
\hline Samozatrudnienie & 4,3 & 5,78 & 7,67 \\
\hline Praca, brak danych o formie zatrudnienia & 1,4 & 1,16 & 0,72 \\
\hline Liczba przypadków & $695^{\text {d }}$ & 519 & 417 \\
\hline
\end{tabular}

a Dotyczy pierwszej pracy podjętej w drugim półroczu roku ukończenia edukacji (lub wykonywanej w tym czasie). Osoby pozostające bez pracy to osoby, które nie wykonywały żadnej pracy w okresie lipiec-grudzień w roku ukończenia edukacji.

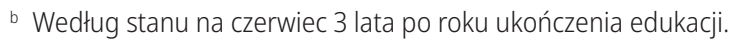

c Według stanu na czerwiec 5 lat po roku ukończenia edukacji.

d Z tej próby wyłączono 11 osób, które ukończyły edukację w roku badania i nie pracowały do momentu badania. W odniesieniu do takich osób nie można określić, czy pozostawały one bez pracy przez całe drugie półrocze roku ukończenia edukacji, ponieważ badanie miało miejsce przed końcem tego okresu.

Źródło: obliczenia własne na podstawie danych POLPAN 2008-2018.

Interpretując wyniki umieszczone w tabeli 1, należy pamiętać, że dane z poszczególnych kolumn dotyczą innej podpróby respondentów. W przypadku podanej w pierwszej kolumnie informacji o sytuacji zatrudnienia po ukończeniu szkoły jest to próba wszystkich absolwentów w wieku 21-35 lat (z wyłączeniem tych, co do których nie było możliwe określenie formy

32 Należy jednak pamiętać o coraz częściej dyskutowanym w ostatnich latach zjawisku tzw. pozornego samozatrudnienia, występującego w firmach, które zamiast bezpośrednio zatrudniać pracowników zawierają kontrakty z samozatrudnionymi podwykonawcami. Pracownicy tego rodzaju, choć formalnie samozatrudnieni, niejednokrotnie wykonują podobne zadania i na podobnych zasadach jak osoby mające umowę o pracę, ale nie podlegają ochronie prawa pracy. Na podstawie danych statystycznych trudno jest precyzyjnie rozróżnić pozornie samozatrudnionych od faktycznych przedsiębiorców. Wymagałoby to osobnych, pogłębionych analiz. 
zatrudnienia), w przypadku danych z pozostałych dwóch kolumn próba jest ograniczona do osób, które ukończyły edukację na tyle wcześnie, że możliwe było odtworzenie przebiegu ich dalszej kariery przez odpowiednio - 3 lata oraz 5 lat. Odsetki przedstawione w tabeli 1 nie są zatem bezpośrednio porównywalne ze sobą. Co ważniejsze, nie niosą one żadnych informacji o zmianach sytuacji zatrudnienia poszczególnych respondentów - w szczególności o odsetku badanych przechodzących z zatrudnienia na czas określony do pracy stałej, kluczowym do oceny stopnia, w jakim niestandardowe formy zatrudnienia stanowią dla młodych pracowników „pomost” bądź „ślepy zaułek”. Przejścia między poszczególnymi kategoriami ukazuje tabela 2. Dane w niej zawarte pozwalają na pierwszą ocenę tego, jak wyglądały dalsze losy zawodowe respondentów w zależności od sytuacji na rynku pracy bezpośrednio po zakończeniu ich edukacji. Dane te sugerują, że sytuacja zatrudnienia respondentów pozostaje stosunkowo stabilna. Dotyczy

Tabela 2. Zatrudnienie respondentów w wieku 21-35 lat (według POLPAN 2018) 3 lata i 5 lat po ukończeniu edukacji w zależności od sytuacji zatrudnienia po ukończeniu edukacji (w \%)
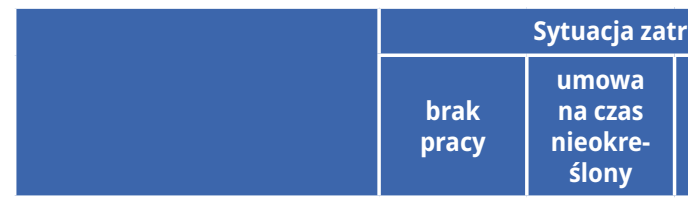

\begin{tabular}{|c|c|}
\hline umowa & bez \\
na czas & umowy \\
określony & o pracę \\
\hline
\end{tabular}

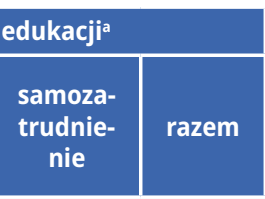

Sytuacja po 3 latach ${ }^{\mathrm{b}}$

\begin{tabular}{|c|c|c|c|c|c|c|}
\hline brak pracy & $\mathbf{4 2 , 8}$ & 3,0 & 12,7 & 23,1 & 8,7 & 24,8 \\
\hline umowa na czas nieokreślony & 24,7 & $\mathbf{8 5 , 9}$ & 25,5 & 20,0 & 21,7 & 36,1 \\
\hline umowa na czas określony & 19,5 & 7,1 & $\mathbf{5 4 , 9}$ & 21,5 & 4,3 & 23,8 \\
\hline bez umowy o pracę & 8,4 & 3,0 & 4,9 & $\mathbf{2 7 , 7}$ & 13,0 & 9,3 \\
\hline samozatrudnienie & 4,7 & 1,0 & 2,0 & 7,7 & 52,2 & 6,0 \\
\hline Sytuacja po 5 latachc & & & & & \\
\hline brak pracy & 35,1 & 4,2 & 12,0 & 23,1 & 4,8 & 22,3 \\
\hline umowa na czas nieokreślony & 31,4 & 81,7 & 44,0 & 30,8 & 23,8 & 42,1 \\
\hline umowa na czas określony & 21,1 & 5,6 & 34,7 & 26,9 & 9,5 \\
\hline bez umowy o pracę & 5,9 & 4,2 & 5,3 & $\mathbf{1 3 , 5}$ & 9,5 \\
\hline samozatrudnienie & 6,5 & 4,2 & 4,0 & 5,8 & $\mathbf{5 2 , 4}$ \\
\hline
\end{tabular}

Dane dotyczą respondentów, których kariery były obserwowane przez 3 lata i 5 lat, z wyłączeniem osób, w których przypadku brakowało danych o formie zatrudnienia (liczebności prób wyniosły odpowiednio - 504 i 404). a Dotyczy pierwszej pracy podjętej w drugim półroczu roku ukończenia edukacji (lub wykonywanej w tym czasie). Osoby pozostające bez pracy to osoby, które nie wykonywały żadnej pracy w okresie lipiec-grudzień w roku ukończenia edukacji.

b Według stanu na czerwiec 3 lata po roku ukończenia edukacji.

c Według stanu na czerwiec 5 lat po roku ukończenia edukacji.

Źródło: obliczenia własne na podstawie danych POLPAN 2008-2018. 
to w szczególności osób, których kariery zawodowe po ukończeniu szkoły lub studiów rozpoczynają się od umów na czas nieokreślony. Aż 86\% spośród tych osób po 3 latach i niemal 82\% po 5 latach nadal posiada stałe zatrudnienie. Nieco większe zróżnicowanie występuje wśród osób, które na rynek pracy weszły jako osoby samozatrudnione - w tej samej sytuacji pozostaje nieco ponad połowa spośród nich. Niepokoić mogą wyniki odnoszące się do pozostawania bez pracy, sugerujące, iż wiele osób spośród tych, które tuż po ukończeniu edukacji miały problemy ze znalezieniem jakiejkolwiek pracy, doświadcza podobnych problemów również w kolejnych latach. Na brak zatrudnienia po 3 bądź 5 latach są narażone również osoby, które rozpoczęły kariery od zatrudnienia bez umowy o pracę - na podstawie umów-zleceń lub umów o dzieło. Patrząc na dane z tabeli 2, możemy też powiedzieć, że choć mechanizm „pomostu” występuje w przypadku części polskich absolwentów (ostatecznie 44\% spośród osób, które po ukończeniu edukacji pracowały z umową na czas określony, po 5 latach ma zatrudnienie na czas nieokreślony), dominuje jednak mechanizm „pułapki”. Podjęcie po ukończeniu szkoły elastycznego zatrudnienia (z umową o pracę lub bez niej) w 56\% przypadków oznacza pozostawanie w tej samej sytuacji po 3 latach, w 40\% po 5 latach. Gdyby do grupy pozostających bez dostępu do stabilnej pracy mimo upływu lat doliczyć osoby niepracujące, uzyskujemy odpowiednio - 72\% i 57\%. Powyższe tendencje mogą świadczyć o ryzyku prekaryzacji młodych absolwentów.

Aby dokładniej ocenić to ryzyko, należy bliżej przyjrzeć się pełnym sekwencjom karier zawodowych respondentów w okresie po ukończeniu przez nich edukacji. W tym celu obserwowane trzy- oraz pięcioletnie sekwencje zostały podzielone w zależności od dominującej w nich formy zatrudnienia. Pierwszy typ sekwencji stanowią te, do których należą wyłącznie prace najemne na podstawie umów na czas nieokreślony. Drugi typ to sekwencje, na które składają się wyłącznie epizody elastycznego zatrudnienia ${ }^{33}$. Zatrudnienie to jest definiowane według deklarowanego kontraktu stanowiącego podstawę stosunku pracy respondenta i uwzględnia: umowy o pracę na czas określony, umowy-zlecenia, umowy o dzieło bądź prace bez formalnej umowy. Trzeci typ sekwencji jest mieszany i obejmuje zarówno elastyczne formy zatrudnienia, jak i prace na podstawie umów na czas nieokreślony. Z próby wyłączono rolników indywidualnych oraz osoby, które przynajmniej raz w ciągu obserwowanej kariery były samozatrudnione. Osobną kategorię stanowią respondenci, którzy nie wykonywali żadnej pracy przez cały okres objęty analizą. Odpowiednie dane przedstawia tabela 3. Szereg przedstawionych w niej wyników może budzić niepokój. Po pierwsze, dość znaczący jest odsetek osób pozostających bez pracy przez 3 lata oraz 5 lat po ukończeniu edukacji (odpowiednio - 15\% oraz 9\%). Po drugie, wśród młodych pracowników powszechne są sytuacje, gdy przez kilka pierwszych lat po opuszczeniu systemu szkolnictwa doświadczali wyłącznie epizodów elastycznego zatrudnienia. W świetle przyjętych założeń to w tej kategorii pracowników mogą znajdować się osoby doświadczające niepewności na rynku pracy. Do takiej interpretacji skłania również porównanie średniej łącznej liczby miesięcy bez pracy przy poszczególnych typach kariery. Dla respondentów, którzy przez 3 lata pracowali wyłącznie na podstawie elastycznych umów, okresy braku pracy sumują się do ponad

33 Teoretycznie możliwa jest sytuacja, w której respondent ma w pracy głównej zatrudnienie na czas określony, ale jednocześnie wykonuje pracę dodatkową na podstawie umowy na czas nieokreślony. W toku analiz okazało się jednak, że w badanej próbie takie sytuacje nie miały miejsca. 
Tabela 3. Typy trajektorii zawodowych respondentów w wieku 21-35 lat (według POLPAN 2018) - rozkłady w próbach oraz liczba miesięcy bez pracy w poszczególnych trajektoriach

\begin{tabular}{|c|c|c|c|c|c|c|}
\hline & \multicolumn{3}{|c|}{$\begin{array}{c}\text { Pierwsze } 3 \text { lata } \\
\text { po ukończeniu edukacji }\end{array}$} & \multicolumn{3}{|c|}{$\begin{array}{c}\text { Pierwsze } 5 \text { lat } \\
\text { po ukończeniu edukacji }\end{array}$} \\
\hline & liczba & odsetek & $\begin{array}{l}\text { miesiące } \\
\text { bez pracy } \\
\text { (średnio) }\end{array}$ & liczba & odsetek & $\begin{array}{l}\text { miesiące } \\
\text { bez pracy } \\
\text { (średnio) }\end{array}$ \\
\hline Cały czas bez pracy & 69 & 14,8 & 36 & 33 & 9,0 & 60 \\
\hline $\begin{array}{l}\text { Wyłącznie praca na czas } \\
\text { nieokreślony }\end{array}$ & 122 & 26,1 & 1,24 & 88 & 24,0 & 2,65 \\
\hline $\begin{array}{l}\text { Wyłącznie elastyczne formy } \\
\text { zatrudnienia }\end{array}$ & 194 & 41,5 & 5,46 & 135 & 36,8 & 12,38 \\
\hline $\begin{array}{l}\text { Prace najemne z różnymi } \\
\text { umowami }\end{array}$ & 82 & 17,6 & 4,58 & 111 & 30,2 & 7,20 \\
\hline Liczba przypadków & 467 & & & 367 & & \\
\hline
\end{tabular}

Dane dotyczą respondentów, których kariery były obserwowane przez 3 lata i 5 lat, z wyłączeniem osób, w których przypadku brakowało danych o formie zatrudnienia, oraz osób samozatrudnionych.

Źródło: obliczenia własne na podstawie danych POLPAN 2008-2018.

5 miesięcy. W przypadku pięcioletniego okresu obserwacji liczba miesięcy bez pracy przekracza 12. Warto tu dodatkowo zwrócić uwagę na osoby, które przez czas objęty analizą ani razu nie posiadały umowy o pracę i były zatrudnione głównie na podstawie umów cywilnoprawnych. Nie jest to bardzo liczna grupa wśród osób realizujących „elastyczny” model kariery (46 osób na 194 osoby w przypadku trzyletniego okresu obserwacji, 24 osoby na 135 osób w przypadku pięcioletniego okresu), ale jest to kategoria szczególnie narażona na ryzyko pozostawania bez pracy (średnia liczba miesięcy bez pracy w tej grupie wyniosła dla obu okresów obserwacji odpowiednio - 7 oraz 19). Jeśli chodzi o kategorię mieszaną, mimo stosunkowo długich okresów bezrobocia obejmuje ona w zdecydowanej większości (ponad 80\% przypadków) kariery, które kończą się uzyskaniem umowy o pracę na czas nieokreślony. Można więc uznać, że w tej kategorii znajdą się osoby, dla których elastyczne zatrudnienie mogło stać się „pomostem” do stabilizacji zawodowej. Choć kategoria ta nie jest liczna w przypadku trzyletniego okresu obserwacji, wydaje się, że po 5 latach od ukończenia edukacji duża część młodych pracowników realizuje ten wzorzec kariery. Nie jest to jednak model dominujący. Patrząc od innej strony, o sile mechanizmu „ślepego zaułka” na polskim rynku pracy można wnioskować na podstawie faktu, że spośród tych, którzy zaczęli karierę od pracy na czas określony lub bez umowy o pracę (w tym umów cywilnoprawnych), 72\% przez kolejne 3 lata i 52\% przez kolejne 5 lat posiadało wyłącznie elastyczne zatrudnienie przeplatane okresami braku pracy.

W tej sytuacji podstawowe pytanie dotyczy tego, jakie kategorie populacji częściej doświadczają mechanizmu "pomostu”, a jakie są narażone na „ślepe zaułki” związane z elastycznym zatrudnieniem. W odpowiedzi na to pytanie może pomóc analiza regresji logistycznej badającej podstawowe społeczno-ekonomiczne korelaty realizacji wzorów karier, które w niniejszym 
artykule zostały wstępnie sklasyfikowane jako naznaczone niepewnością. Zmienna zależna identyfikuje respondentów, którzy w tabeli 3 zostali zaliczeni do kategorii realizujących kariery oparte w całości na elastycznych formach zatrudnienia, kategorią referencyjną zaś są respondenci, którzy przynajmniej raz w karierze posiadali umowę o pracę na czas nieokreślony. Osoby, które nie pracowały przez cały okres objęty analizą, oraz osoby samozatrudnione zostały wyłączone z próby. Wśród zmiennych niezależnych zostały uwzględnione płeć oraz poziom zdobytego wykształcenia w podziale na pięć kategorii: poniżej średniego (w tym podstawowe bądź gimnazjalne oraz zasadnicze zawodowe), średnie ogólnokształcące, wyższe licencjackie (w tym szkoła policealna) oraz wyższe magisterskie. Zawód wykonywany w pierwszej pracy jest kolejną ważną zmienną, co wynika z założenia, że uzyskanie na wczesnym etapie kariery doświadczenia zawodowego w pracy o wyższych wymogach kwalifikacyjnych może zwiększać szanse jednostek na rynku pracy. Kategoria zawodowa (pierwsza praca) została zdefiniowana na podstawie jednocyfrowej Społecznej Klasyfikacji Zawodów ${ }^{34}$. Ze względu na niewielką liczebność niektórych kategorii trzy spośród nich - kierownicy, specjaliści oraz technicy - zostały połączone w jedną kategorię referencyjną zawodów charakteryzujących się najwyższym poziomem złożoności pracy. Wśród zmiennych kontrolnych uwzględniono rok ukończenia szkoły przez respondentów, jak również dodatkowy wskaźnik opisujący doświadczenie zawodowe badanych przed ukończeniem przez nich edukacji (czy pracowali przed ukończeniem szkoły).

Współczynniki regresji logistycznej przedstawione w tabeli 4 wskazują, że sekwencji elastycznego zatrudnienia - zarówno trzy-, jak i pięcioletnich - wyraźnie częściej doświadczały kobiety. Z tabeli wynika również, że posiadanie wyższego wykształcenia (nawet na poziomie licencjatu) w znaczącym stopniu obniża ryzyko niepewności zatrudnienia. Warto jednak zaznaczyć, że zależność między poziomem wykształcenia a typem kariery po jego uzyskaniu nie ma charakteru liniowego - w szczególności nie zaobserwowano istotnych różnic między osobami, które posiadają wykształcenie podstawowe bądź zasadnicze zawodowe, a absolwentami liceów ogólnokształcących. Nieco lepiej radzą sobie absolwenci techników, choć z uwagi na niską liczebność próby różnica między nimi a kategorią referencyjną nie jest istotna statystycznie. Znaczenie ma również zawód wykonywany w pierwszej pracy po ukończeniu edukacji - na niepewność zatrudnienia są narażone przede wszystkim osoby, które karierę rozpoczęły od pracy w zawodzie robotnika, w nieco mniejszym stopniu pracownicy usług oraz sprzedawcy. Wydaje się, iż oddziaływanie poziomu wykształcenia na dalszą karierę ma miejsce poprzez wpływ na wykonywany zawód - dodatkowe analizy wykazały, że po dodaniu zmiennych identyfikujących kategorie zawodowe do równania zależność między posiadaniem wyższego wykształcenia na poziomie magistra lub wyższym a niepewnością zatrudnienia przestaje być istotna statystycznie. Co jednak ciekawe, negatywny związek między zmienną zależną a wykształceniem wyższym licencjackim (lub policealnym) pozostaje istotny statystycznie niezależnie od zawodu wykonywanego w pierwszej pracy po ukończeniu studiów. Na koniec wypada zauważyć, iż sam fakt wykonywania jakiejkolwiek pracy w okresie edukacji nie wydaje się mieć znaczenia dla

34 Nowa klasyfikacja i skale zawodów. Socjologiczne wskaźniki pozycji społecznej w Polsce, red. H. Domański, Z. Sawiński, K.M. Słomczyński, Wydawnictwo IFiS PAN, Warszawa 2007. 
Tabela 4. Wyniki analizy regresji logistycznej dla ścieżek karier, w których skład wchodzą wyłącznie prace na czas określony lub bez umowy o pracę

\begin{tabular}{|c|c|c|c|c|c|c|c|c|}
\hline & \multicolumn{4}{|c|}{$\begin{array}{c}\text { Pierwsze } 3 \text { lata po ukończeniu } \\
\text { edukacji }\end{array}$} & \multicolumn{4}{|c|}{$\begin{array}{c}\text { Pierwsze } 5 \text { lat po ukończeniu } \\
\text { edukacji }\end{array}$} \\
\hline & \multicolumn{2}{|c|}{ model 1a } & \multicolumn{2}{|c|}{ model 1b } & \multicolumn{2}{|c|}{ model 2a } & \multicolumn{2}{|c|}{ model $2 b$} \\
\hline & B & $\begin{array}{l}\text { iloraz } \\
\text { Szans }\end{array}$ & B & $\begin{array}{l}\text { iloraz } \\
\text { Szans }\end{array}$ & B & $\begin{array}{l}\text { iloraz } \\
\text { Szans }\end{array}$ & B & $\begin{array}{l}\text { iloraz } \\
\text { szans }\end{array}$ \\
\hline Płeć: kobieta & $\begin{array}{r}0,927 \\
(0,235)\end{array}$ & $2,53^{\star \star \star}$ & $\begin{array}{r}1,000 \\
(0,248)\end{array}$ & $2,72^{* \star *}$ & $\begin{array}{r}0,875 \\
(0,267)\end{array}$ & 2,40 ** & $\begin{array}{r}0,951 \\
(0,288)\end{array}$ & $2,59 * * *$ \\
\hline \multicolumn{9}{|l|}{ Poziom wykształcenia } \\
\hline $\begin{array}{l}\text { średnie } \\
\text { ogólnokształcące }\end{array}$ & $\begin{array}{r}0,118 \\
(0,424)\end{array}$ & $\begin{array}{l}1,13 \\
(0,437)\end{array}$ & & & $-0,012$ & 0,99 & & \\
\hline średnie zawodowe & $\begin{array}{l}-0,367 \\
(0,331)\end{array}$ & 0,69 & & & $\begin{array}{l}-0,475 \\
(0,358)\end{array}$ & 0,62 & & \\
\hline $\begin{array}{l}\text { wyższe licencjackie } \\
\text { i policealne }\end{array}$ & $\begin{array}{l}-1,617 \\
(0,410)\end{array}$ & $0,20^{\star \star \star}$ & & & $\begin{array}{l}-1,594 \\
(0,476)\end{array}$ & $0,20^{\star \star *}$ & & \\
\hline wyższe magisterskie & $\begin{array}{l}-1,333 \\
(0,364)\end{array}$ & $0,26^{\star \star \star}$ & & & $\begin{array}{l}-1,429 \\
(0,409)\end{array}$ & $0,24^{\star \star *}$ & & \\
\hline \multicolumn{9}{|l|}{ Pierwszy zawód } \\
\hline pracownicy biurowi & & & $\begin{array}{r}0,026 \\
(0,331)\end{array}$ & 1,03 & & & $\begin{array}{r}0,358 \\
(0,413)\end{array}$ & 1,43 \\
\hline $\begin{array}{l}\text { pracownicy usług } \\
\text { i sprzedawcy }\end{array}$ & & & $\begin{array}{r}0,762 \\
(0,319)\end{array}$ & $2,14^{*}$ & & & $\begin{array}{r}1,085 \\
(0,394)\end{array}$ & $2,96^{\star *}$ \\
\hline $\begin{array}{l}\text { robotnicy } \\
\text { wykwalifikowani }\end{array}$ & & & $\begin{array}{r}1,215 \\
(0,333)\end{array}$ & $3,37^{* * *}$ & & & $\begin{array}{r}1,457 \\
(0,411)\end{array}$ & $4,29 * * *$ \\
\hline $\begin{array}{l}\text { robotnicy } \\
\text { niewykwalifikowani }\end{array}$ & & & $\begin{array}{r}1,644 \\
(0,375)\end{array}$ & $5,18^{* \star *}$ & & & $\begin{array}{r}1,759 \\
(0,413)\end{array}$ & $5,81^{* * *}$ \\
\hline Rok ukończenia edukacji & $\begin{array}{r}0,043 \\
(0,036)\end{array}$ & 1,04 & $\begin{array}{r}0,054 \\
(0,037)\end{array}$ & 1,05 & $\begin{array}{r}0,019 \\
(0,048)\end{array}$ & 1,02 & $\begin{array}{r}0,042 \\
(0,050)\end{array}$ & 1,04 \\
\hline $\begin{array}{l}\text { Pracujący przed } \\
\text { ukończeniem edukacji }\end{array}$ & $\begin{array}{l}-0,236 \\
(0,245)\end{array}$ & 0,79 & $\begin{array}{l}-0,452 \\
(0,232)\end{array}$ & $0,64^{\circ}$ & $\begin{array}{l}-0,051 \\
(0,282)\end{array}$ & 0,95 & $\begin{array}{l}-0,268 \\
(0,272)\end{array}$ & 0,77 \\
\hline Logarytm wiarygodności & $-252,96$ & & $-254,15$ & & $-189,56$ & & $-188,79$ & \\
\hline$R^{2}$ Coxa i Snella & 0,108 & & 0,103 & & 0,098 & & 0,103 & \\
\hline$R^{2}$ Nagelkerkego & 0,144 & & 0,137 & & 0,133 & & 0,139 & \\
\hline $\mathrm{Chi}^{2}$ & 45,578 & & 43,201 & & 31,600 & & 33,147 & \\
\hline N & 398 & & & & 306 & & & \\
\hline
\end{tabular}

Współczynniki regresji logistycznej obliczone na próbach respondentów, których kariery były obserwowane przez 3 lata i 5 lat, z wyłączeniem osób, w których przypadku brakowało danych o formie zatrudnienia, oraz osób samozatrudnionych (błędy standardowe podano w nawiasach). Kategorie referencyjne dla zmiennych niezależnych są następujące: dla poziomu wykształcenia - wykształcenie podstawowe, gimnazjalne lub zasadnicze zawodowe; dla grupy zawodowej - kierownicy, specjaliści i technicy.

${ }^{* * *} p<0,001 ; * * p<0,01 ;{ }^{*} p<0,05 ;{ }^{\circ} p<0,1$.

Źródło: obliczenia własne na podstawie danych POLPAN 2008-2018. 
przebiegu późniejszej kariery. Choć współczynniki regresji dla tej zmiennej wskazują na zgodną z przewidywaniem negatywną zależność, ich wysokość tylko w jednym modelu (1b) nieznacznie przekroczyła próg statystycznej istotności. Powyższy wynik nie musi oznaczać, że doświadczenie zawodowe uzyskane w czasie studiów jest bezwartościowe, wskazuje on jednak na konieczność zastosowania bardziej precyzyjnych wskaźników, pozwalających uchwycić nie tylko samą obecność takiego doświadczenia, lecz także jego znaczenie jako czynnika rozwoju kapitału ludzkiego (zależne np. od charakteru wykonywanej pracy i długości jej trwania).

\section{Wnioski}

Analizy danych dotyczących przebiegu karier wskazują, że niepewność zatrudnienia wśród młodych dorosłych w Polsce stanowi ważny problem, o potencjalnie dość szerokim zasięgu. Choć pełna ocena prekaryzacji zatrudnienia wymagałaby wzięcia pod uwagę różnych aspektów sytuacji rodzinnej i materialnej respondentów, a wielkość próby osób z badanej kategorii wiekowej, w których przypadku są dostępne pełne dane o historii zatrudnienia przez pierwsze 5 lat od zakończenia edukacji, nie pozwala na dokładną ocenę rozmiarów zjawiska, na podstawie przeprowadzonych analiz można ostrożnie szacować, że nawet co trzeci absolwent w Polsce doświadczył przedłużających się problemów ze znalezieniem stabilnego zatrudnienia z umową o pracę na czas nieokreślony. Jest to rezultat dość zaskakujący, jeśli wziąć pod uwagę dobrą koniunkturę na rynku pracy w ostatnich latach. Choć, oczywiście, dla części respondentów moment rozpoczęcia kariery przypadł na lata wcześniejsze, charakteryzujące się trudniejszą sytuacją na rynku pracy, w analizach regresji nie zaobserwowano wyraźnej zależności między ryzykiem niepewności zatrudnienia a rokiem ukończenia szkoły. Warto zarazem pamiętać, iż dopiero w listopadzie 2018 r., a więc tuż po realizacji ostatniej fali badania POLPAN, po raz pierwszy od wejścia w życie nowelizacji Kodeksu pracy ograniczającej maksymalną długość zatrudnienia na czas określony u jednego pracodawcy do 33 miesięcy minął wprowadzony wówczas limit czasowy. Biorąc pod uwagę fakt, że w świetle deklaracji badanych wśród elastycznych form zatrudnienia po 5 latach od ukończenia edukacji dominują umowy o pracę na czas określony, umowy cywilnoprawne (których limit nie dotyczy) zaś oraz samozatrudnienie występują stosunkowo rzadko, nie można wykluczyć, że dla jakiejś części młodych dorosłych w kolejnych miesiącach po badaniu umowy o pracę na czas określony uległy z mocy prawa przekształceniu w umowy na czas nieokreślony. Zarazem zbliżający się moment osiągnięcia limitu może zwiększać ryzyko utraty pracy w wyniku wypowiedzenia umowy przez pracodawcę dążącego do uniknięcia konieczności zatrudnienia na czas nieokreślony. Istnienie wspomnianego zagrożenia, które w okresie spowolnienia gospodarczego może jeszcze wzrosnąć, oznacza konieczność dokładnej obserwacji tendencji zatrudniania młodych w nadchodzących latach.

Zaprezentowane w artykule wyniki wyraźnie wskazują na występowanie w Polsce dwóch przeciwstawnych scenariuszy dla osób rozpoczynających kariery od elastycznego zatrudnienia - „pomostu” oraz „ślepego zaułka”. Po pierwsze, oznacza to, że rzetelna diagnoza problemu niepewności na rynku pracy wymaga sięgnięcia do danych panelowych, umożliwiających analizę przebiegu karier zawodowych. Badania takie jak POLPAN, gromadzące szczegółowe dane 
o pełnych biografiach zawodowych respondentów, są kluczowym źródłem informacji do takich analiz. Po drugie, należy też stwierdzić, że często rozważane w literaturze przedmiotu pytanie o ogólne skutki zatrudnienia na czas określony dla dalszego przebiegu karier pracowników jest pytaniem źle postawionym. Skutki te mogą być dwojakie, stąd ważniejszym - również z praktycznego punktu widzenia - problemem badawczym jest ustalenie, od jakich czynników i charakterystyk te skutki zależą. Choć w ostatnich latach rośnie liczba analiz dynamiki karier pracowników, zdecydowana większość badań koncentruje się na wyjaśnieniu różnic na poziomie makro (między poszczególnymi państwami) ${ }^{35}$. Analizy badające wpływ indywidualnych charakterystyk pracowników na ryzyko przedłużającej się niestabilności są nadal stosunkowo nieliczne.

W świetle wyników analizy danych POLPAN możemy powiedzieć, że na przedłużającą się niepewność zatrudnienia bardziej narażone są osoby o słabszej pozycji na rynku pracy: kobiety, pracownicy gorzej wykształceni, wykonujący mniej złożone prace. W odniesieniu do sytuacji kobiet powyższy rezultat jest spójny z wynikami badań prowadzonych we Francji i Włoszech ${ }^{36}$. Wskazuje on na konieczność rozwijania programów wsparcia dla pracujących matek, które są zagrożone nie tylko wypadnięciem z rynku pracy, lecz również niestabilnością zawodową. Kolejna konstatacja, dotycząca relatywnie korzystniejszej sytuacji osób posiadających wyższe wykształcenie, jest zgodna z przewidywaniami wywiedzionymi z teorii. Warto jednak zaznaczyć, że edukacja wydaje się chronić przed niepewnością zatrudnienia przede wszystkim tych absolwentów, którzy mają dostęp do zawodów wykorzystujących ich kwalifikacje i dających cenione na rynku pracy doświadczenie ${ }^{37}$. Niezależnie od powyższych rezultatów trzeba pamiętać o wynikach badań zagranicznych sugerujących, że w ostatnich latach problem prekaryzacji zatrudnienia coraz częściej odnosi się też do wykształconych przedstawicieli wolnych zawodów $^{38}$. Powyższe tendencje, dotykające w pierwszym rzędzie osoby młode, mogą nasilać się w nadchodzących latach także w Polsce.

Analizy danych POLPAN, pozbawione odniesień międzynarodowych, umożliwiają diagnozę problemu niepewności na rynku pracy, lecz nie pozwalają odpowiedzieć na pytanie o możliwe środki zaradcze. Odpowiedź na takie pytanie wymagałaby sięgnięcia do porównywalnych danych opisujących biografie zawodowe młodych dorosłych w różnych krajach. Takie dane są opracowywane w ramach trwającego obecnie projektu finansowanego przez Narodowe Centrum Nauki „Dynamika niepewności zatrudnienia młodych: uwarunkowania, trajektorie i skutki

35 C. Brzinsky-Fay, Lost in Transition? Labour Market Entry Sequences of School Leavers in Europe , European Sociological Review" 2007, vol. 23, no. 4, https://doi.org/10.1093/esr/jcm011.

36 P. Barbieri, S. Scherer, Labour Market Flexibilization and its Consequences in Italy, „European Sociological Review" 2009, vol. 25, no. 6, https://doi.org/10.1093/esr/jcp009; V. Gash, F. McGinnity, Fixed-term contracts - the new European inequality? Comparing West Germany and France, "Socio-Economic Review" 2007, vol. 5, no. 3, https://doi.org/10.1093/ser/mwl020.

37 J.H. Goldthorpe, O socjologii. Integracja badań i teorii, Wydawnictwo IFiS PAN, Warszawa 2012.

38 J.C. Dencker, Corporate restructuring and the employment relationship [w:] Employment Relationships: New Models of White-Collar Work, red. P. Capelli, Cambridge University Press, Cambridge 2008; S. Häusermann, T. Kurer, H. Schwander, High-skilled outsiders? Labor market vulnerability, education and welfare state preferences, „Socio-Economic Review” 2015, vol. 13, no. 2, https://doi.org/10.1093/ser/mwu026. 
w perspektywie porównawczej", realizowanego przez konsorcjum Uniwersytetu Warszawskiego oraz Instytutu Filozofii i Socjologii Polskiej Akademii Nauk ${ }^{39}$. Prowadzone w ramach projektu badania pozwolą na pogłębione analizy sposobu, w jaki wzajemne oddziaływanie charakterystyk jednostek i konkretnych rozwiązań z zakresu polityk publicznych określa szanse stabilizacji zawodowej lub łagodzi negatywne skutki niestabilności na wczesnym etapie kariery zawodowej.

\section{Bibliografia}

Aassve A., Cottini E., Vitali A., Youth prospects in a time of economic recession, „Demographic Research” 2013, vol. 29, no. 36, https://doi.org/10.4054/DemRes.2013.29.36.

Barański M., Determinants of Temporary Employment in Poland, "Warsaw Forum of Economic Sociology” 2014, vol. 5, no. 1(9).

Barbieri P., Scherer S., Labour Market Flexibilization and its Consequences in Italy , "European Sociological Review" 2009, vol. 25, no. 6, https://doi.org/10.1093/esr/jcp009.

Bauman Z., Płynna nowoczesność, Wydawnictwo Literackie, Kraków 2006.

Beck U., Beck-Gernsheim E., Individualisation: Institutionalized Individualism and Its Social and Political Consequences, Sage, London 2002.

Booth A.L., Francesconi M., Frank J., Temporary jobs: stepping stones or dead ends? , "The Economic Journal” 2002, vol. 112, no. 480, https://doi.org/10.1111/1468-0297.00043.

Brzinsky-Fay C., Lost in Transition? Labour Market Entry Sequences of School Leavers in Europe „ European Sociological Review" 2007, vol. 23, no. 4, https://doi.org/10.1093/esr/jcm011.

Chung H., Mau S., Subjective insecurity and the role of institutions, "Journal of European Social Policy" 2014, vol. 24, no. 4, https://doi.org/10.1177/0958928714538214.

Cybal-Michalska A., Młodzież w relacji do kariery jako "własności" zawodu albo "roli zawodowej" - perspektywa funkcjonalno-strukturalna , „Studia Edukacyjne” 2016, nr 38, https://doi.org/10.14746/se.2016.38.4.

Dencker J.C., Corporate restructuring and the employment relationship [w:] Employment Relationships: New Models of White-Collar Work, red. P. Capelli, Cambridge University Press, Cambridge 2008.

Doeringer P.B., Piore M.J., Internal Labor Markets and Manpower Analysis, Heath Lexington Books, Lexington 1971. European Commission, Employment and Social Developments in Europe 2015, Publications Office of the European Union, Luxembourg 2016.

Faccini R., Reassessing Labour Market Reforms: Temporary Contracts as a Screening Device, "The Economic Journal” 2013, vol. 124, no. 575, https://doi.org/10.1111/ecoj.12072.

Fenton S., Dermott E., Fragmented Careers?: Winners and Losers in Young Adult Labour Markets, „Work, Employment and Society" 2006, vol. 20, no. 2, https://doi.org/10.1177/0950017006064111.

Fevre R., Employment Insecurity and Social Theory: The Power of Nightmares, "Work, Employment and Society” 2007, vol. 21, no. 3, https://doi.org/10.1177/0950017007080013.

Fuller S., Stecy-Hildebrandt N., Career Pathways for Temporary Workers: Exploring Heterogeneous Mobility Dynamics with Sequence Analysis, "Social Science Research” 2015, vol. 50, https://doi.org/10.1016/j.ssresearch.2014.11.003.

39 Szczegółowe informacje znajdują się na stronie internetowej projektu: www.crossnationalbiographies.edu.pl. 
Gash V., Bridge or trap? Temporary workers' transitions to unemployment and to the standard employment contract, „European Sociological Review” 2008, vol. 24, no. 5, https://doi.org/10.1093/esr/jcn027.

Gash V., McGinnity F., Fixed-term contracts - the new European inequality? Comparing West Germany and France, „Socio-Economic Review” 2007, vol. 5, no. 3, https://doi.org/10.1093/ser/mwl020.

Goldthorpe J.H., O socjologii. Integracja badań i teorii, Wydawnictwo IFiS PAN, Warszawa 2012.

Häusermann S., Kurer T., Schwander H., High-skilled outsiders? Labor market vulnerability, education and welfare state preferences, „Socio-Economic Review” 2015, vol. 13, no. 2, https://doi.org/10.1093/ser/mwu026.

Hipp L., Bernhardt J., Allmendinger J., Institutions and the Prevalence of Nonstandard Employment, „Socio-Economic Review" 2015, vol. 13, no. 2, https://doi.org/10.1093/ser/mwv002.

Högberg B., Strandh M., Baranowska-Rataj A., Transitions from Temporary Employment to Permanent Employment among Young Adults: The Role of Labour Law and Education Systems, ,Journal of Sociology" 2019, vol. 55, no. 4, https://doi.org/10.1177/1440783319876997.

Kalleberg A.L., Precarious work, insecure workers: employment relations in transition, „American Sociological Review” 2009, vol. 74, no. 1, https://doi.org/10.1177/000312240907400101.

Karolak M., Społeczno-ekonomiczne konteksty prekaryzacji pracy młodych w Polsce [w:] Oswajanie niepewności. Studia społeczno-ekonomiczne nad młodymi pracownikami sprekaryzowanymi, red. A. Mrozowicki, J. Czarzasty, Wydawnictwo Naukowe Scholar, Warszawa 2020.

Kiersztyn A., Fixed-Term Employment and Occupational Position in Poland: The Heterogeneity of Temporary Jobs, „European Sociological Review” 2016, vol. 32, no. 6, https://doi.org/10.1093/esr/jcw044.

Kiersztyn A., Labour market precarity and political alienation, „Przegląd Socjologiczny” 2018, vol. 67, no. 3, https:// doi.org/10.26485/Ps/2018/67.3/2.

Kiersztyn A., Non-standard employment and subjective insecurity. How can we capture job precarity using survey data? [w:] Precarious Work, Research in the Sociology of Work Series, red. A. Kalleberg, S. Vallas, Emerald Publishing, Bingley 2017.

Kiersztyn A., Voice and Insecurity. Political Participation among Members of the Precariat [w:] Civil Society Revisited: Lessons from Poland, red. K. Jacobsson, E. Korolczuk, Berghahn Books, New York-Oxford 2017.

Lewchuk W., Precarious Jobs: Where Are They, and How Do They Affect Well-Being? "The Economic and Labour Relations Review" 2017, vol. 28, no. 3, https://doi.org/10.1177/1035304617722943.

Marler J.H., Barringer M., Milkovich G.T., Boundaryless and traditional contingent employees: Worlds apart, „Journal of Organizational Behavior" 2002, vol. 23, no. 4, https://doi.org/10.1002/job.148.

McGovern P., Smeaton D., Hill S., Bad Jobs in Britain. Nonstandard Employment and Job Quality, „Work and Occupations" 2004, vol. 31, no. 2, https://doi.org/10.1177/0730888404263900.

Mills M., Blossfeld H.-P., Globalization, uncertainty and the early life course: A theoretical framework [w:] Globalization, uncertainty and youth in society, red. H.-P. Blossfeld, E. Klijzing, M. Mills, K. Kurz, Routledge, London-New York 2005.

Mrozowicki A., Normalisation of Precariousness? Biographical Experiences of Young Workers in the Flexible Forms of Employment in Poland, „Przegląd Socjologii Jakościowej” 2016, t. 12, nr 2.

Mrozowicki A. et al., Prekaryzacja pracy a świadomość społeczna i strategie życiowe ludzi młodych: ramy teoretyczne [w:] Oswajanie niepewności. Studia społeczno-ekonomiczne nad młodymi pracownikami sprekaryzowanymi, red. A. Mrozowicki, J. Czarzasty, Wydawnictwo Naukowe Scholar, Warszawa 2020.

Nowa klasyfikacja i skale zawodów. Socjologiczne wskaźniki pozycji społecznej w Polsce, red. H. Domański, Z. Sawiński, K.M. Słomczyński, Wydawnictwo IFiS PAN, Warszawa 2007. 
Nyhagen Predelli L., Cebulla A., Perceptions of labour market risks: shifts and continuities across generations, "Current Sociology" 2011, vol. 59, no. 1, https://doi.org/10.1177/0011392110385968.

O'Connell P. J., Byrne D., The determinants and effects of training at work: bringing the work-place back in, „European Sociological Review" 2012, vol. 28, no. 3, https://doi.org/10.1093/esr/jcq063.

Piorunek M., Kariera według młodych, czyli nowy paradygmat kariery na dysonansowym rynku pracy, „Studia Edukacyjne" 2016, nr 38, https://doi.org/10.14746/se.2016.38.6.

Quesnel-Vallee A., DeHaney S., Ciampi A., Temporary work and depressive symptoms: A propensity score analysis, „Social Science and Medicine” 2010, vol. 70, no. 12, https://doi.org/10.1177/0143831X14559781.

Schmitt C., Labour market integration, occupational uncertainties, and fertility choices in Germany and the UK, „Demographic Research” 2012, vol. 26, no. 12, https://doi.org/10.4054/DemRes.2012.26.12.

Sennett R., Korozja charakteru. Osobiste konsekwencje pracy w nowym kapitalizmie, Muza, Warszawa 2006.

Słomczyński K.M., Wprowadzenie. Kariera i sukces jako przedmiot badań socjologicznych [w:] Kariera i sukces. Analizy socjologiczne, red. K.M. Słomczyński, Uniwersytet Zielonogórski, Zielona Góra 2007.

Standing G., Prekariat. Nowa niebezpieczna klasa, Wydawnictwo Naukowe PWN, Warszawa 2014.

Szafraniec K., Młodzi 2011, Kancelaria Prezesa Rady Ministrów, Warszawa 2011.

Virtanen M. et al., Temporary employment and health: a review, „International Journal of Epidemiology” 2005, vol. 34, no. 3, https://doi.org/10.1093/ije/dyi024. 